doi:10.1016/j.puhe.2005.09.008

Copyright (c) 2005 The Royal Institute of Public Health Published by Elsevier Ltd.

\title{
Non-response in a survey of cardiovascular risk factors in the Dutch population: Determinants and resulting biases
}

\author{
H.C. Boshuizen ${ }^{a, *}$, A.L. Viet ${ }^{b}$, H.S.J. Picavet ${ }^{b}$, A. Botterweck ${ }^{c}$ and A.J.M. \\ van Loon ${ }^{\mathrm{b}}$
}

${ }^{a}$ Department of Information Technology and Methodology, National Institute for Public Health and the Environment, P.O. Box 1, 3720 BA Bilthoven, The Netherlands

${ }^{b}$ Department of Prevention and Healthcare Research, National Institute for Public Health and the Environment, Bilthoven, The Netherlands

'Statistics Netherlands, Division of Social and Spatial Statistics, Statistical

Analysis, Heerlen, The Netherlands

* Corresponding author. Tel.: +31 30274 2944; fax: +3130274 4456 .

\section{Summary}

\section{Background}

The aim of the research was to study the determinants of participation in a health examination survey (HES) which was carried out in a population that previously participated in a health interview survey (HIS) of Statistics Netherlands, and to estimate the effect of non-participation on both the prevalence of the main HES outcomes (risk factors for cardiovascular disease) and on relationships between variables.

\section{Methods}

Logistic regression was used to study the determinants of participation in the HES $(n=3699)$ by those who had previously participated in the HIS $(n=12786)$. Linear models were used to predict the main outcomes in non-participants of the HES. Item non-response was handled by multiple imputation.

\section{Results}

HES participants had a higher socio-economic status and comprised more 'worried well', while the rural population were less likely to participate in the HES. Most predicted values of outcomes in HES non-participants differed from those in HES participants, but much of this was due to differences in the age and gender composition of both groups. Taking age and gender differences into account, most predicted values of outcomes in the entire HIS population were within the $95 \%$ confidence intervals of the HES values, with the exception of body height in men and high-density lipoprotein cholesterol, fasting glucose and body weight in women. These differences are most likely to be due to the higher socio-economic status of HES participants. Relationships between HIS variables did not change significantly when using HES participants alone compared with all HIS participants. 


\section{Conclusions}

Despite a high rate of non-participation, some bias, mostly small, was seen in the prevalence rates of the main outcome variables. Bias in the relationships between variables was negligible.

\section{Introduction}

Monitoring of endogenous risk factors for cardiovascular disease (blood pressure, cholesterol, weight etc.) in a population is carried out by means of health examination surveys (HES). One approach is to link a HES to an existing health interview survey (HIS) by recruiting HIS respondents for participation in the HES. This method was used in the US NHANES study, and was adopted in 1998 in the Regenboog Study (Risk Factors and Health in The Netherlands; a Survey in Municipal Health Services). Linking the HES to the HIS carried out by Statistics Netherlands made it possible to use a nationwide representative population sample. Several studies have been undertaken on the non-response to the Dutch HIS. $^{1,2,3,4 \text { and } 5}$ In agreement with other studies on non-response, ${ }^{6,7,8,9,10}$ and 11 they have found that non-responders to the HIS have a lower socio-economic status and a lower healthcare use than responders.

In this HIS/HES design, participants had several opportunities to decline to participate. At the end of a lengthy interview, they were asked to give consent for their address to be forwarded to the organization carrying out the HES. After being invited to participate, they could have decided not to. Finally, they had to visit the municipal health centre after accepting this invitation. As such, only $29 \%$ of the interviewed HIS participants participated in the HES.

Relatively little is known about selection mechanisms in second-stage nonresponse in a HIS/HES design. This selection takes place in a population that has already been willing to participate in health research. Therefore, other mechanisms may operate compared with those operating when an individual refuses an initial interview. Also, the reasons for being willing to participate in a physical examination could differ from those for being willing to respond to a questionnaire survey. A few studies have investigated non-participation in the HES part of NHANES, ${ }^{12}$ and have indicated a higher response rate among the 'worried well' (those with high healthcare use despite good health), those with more cars in the household, and those living near the location of the examination. In the Welsh Heart Health Survey, ${ }^{13}$ subjects who consented to a medical examination had a higher socio-economic status and a healthier lifestyle (diet, physical activity) than non-consenters. However, as the participation rates in NHANES were much larger than in the present study, the non-participation mechanisms may differ. In the Welsh Heart Health Survey, the consent rates were of equal magnitude to the examination consent rates in the first stage of the present study, but only differences between consenters and non-consenters were studied. In the present study, only half of the consenters actually participated.

As extensive health information was available in the present study for all subjects who participated in the HIS, regardless of whether they participated in the HES, it was possible to study the determinants and consequences of second-stage nonparticipation.

The aims of this paper are:

1. to describe the determinants of non-participation in the HES amongst HIS responders; 
2. to quantify how estimates of the outcomes monitored are influenced by selective non-response; and

3. to describe the magnitude of bias due to non-response in associations as observed in HES participants by comparing associations between HIS variables in analyses using all HIS participants, and analyses using HES participants alone.

\section{Methods}

\section{Survey design}

The HIS carried out by Statistics Netherlands is a nationwide survey on health, use of health services and occupational health. The population comprised HIS participants (1998-2000) aged at least 12 years in regions with municipal health centres participating in the HES $(n=12,786)$. At the end of a full interview, they were asked for their consent for an additional health examination. In The Netherlands, 46 municipal health centres supply public health services to the entire population, including rural areas. Most centres commenced participation in the latter half of 1998. The number of participating municipal health centres increased from five in May 1998 to 42 in December 2000. Consent was obtained from 7431 of 12786 (58\%) people who were subsequently invited by telephone to the municipal health centre for a physical examination. In total, 3699 subjects participated in the HES (29\%).

\section{Health interview survey}

Detailed information on the design of the HIS can be found elsewhere. ${ }^{14}$ In short, a multistage probability sample was drawn of the entire Dutch population after stratification by geographic area and degree of urbanization. The sampling frame excluded those living in institutions (prisons, homes for the elderly, mentally handicapped etc.). Only subjects fluent in Dutch were included and they were visited at home by the interviewer. In the first 4 months of 2004, lack of fluency in Dutch was the reason for non-response in $0.4 \%$ of those of Dutch descent or second-generation immigrants in the sample frame, for $7.9 \%$ of first-generation immigrants from Western countries, and for $18.2 \%$ of immigrants from other countries, ${ }^{15}$ so this criterion will have decreased the presence of ethnic-minority groups in the HIS participants. Those who refused to take part or who could not be contacted after three visits were contacted by telephone in order to administer, if possible, a short interview and (in case of no earlier contact) to make an appointment for a full interview.

During 1998-2000, the average response to the full HIS interview was $56.2 \%$ (of those in the sample frame), and $4.3 \%$ only answered the short telephone questionnaire. Only the respondents who participated in the full interview are included in the present paper. The full HIS interview used two data-collection methods: a computer-aided face-to-face interview and a self-administered mailback questionnaire (for the more personal questions on health). Due to the computer-aided interview format, item non-response was less than $1 \%$ for most items. Exceptions were questions on smoking (1.1\%, including inconsistent answers), educational level $(1.2 \%)$, body weight $(3.4 \%)$ and household income $(22.4 \%)$. The mail-back questionnaire, which included questions on the presence of chronic diseases such as diabetes, was returned by $75 \%$ of the 12,786 interviewees. 


\section{Health examination survey}

Participants completed an informed consent form. When the examination was scheduled before 10.30 a.m., participants were asked to fast from 10.00 p.m. the day before. The examination was carried out by a trained nurse and consisted of the measurement of blood pressure (duplicate measurement with the automatic Omron HEM 711 with 5 min of rest before and between the measurements), weight, height, waist and hip circumferences, and 10 joint function tests. Blood samples were collected for measuring fasting glucose, total cholesterol and highdensity lipoprotein (HDL) cholesterol. The number of missing values was $<1 \%$ in the direct measurements and $8 \%$ in the laboratory values. Fasting glucose concentration was not present for $37 \%$, mainly because of participants examined after 10.30 a.m., but also because some participants forgot to fast.

This paper is restricted to the main outcomes: blood pressure, weight, height, total and $\mathrm{HDL}$ cholesterol, and fasting glucose.

\section{Statistical analyses}

Using existing knowledge and preliminary analyses, 86 variables from the HIS were selected for this analysis. Variables selected were either potential determinants of non-response or of one of the outcomes of interest (Table 1). 
Table 1.

Areas from which items were used in the analyses (sometimes multiple variables were used per area).

\begin{tabular}{|c|c|c|c|c|}
\hline Sociodemographic & $\begin{array}{l}\text { Lifestyle } \\
\text { and antro- } \\
\text { pometry }\end{array}$ & Work & $\begin{array}{l}\text { Health } \\
\text { state/wellbeing }\end{array}$ & $\begin{array}{l}\text { Healthcare } \\
\text { use }\end{array}$ \\
\hline Age & Smoking & $\begin{array}{l}\text { Number of hours paid } \\
\text { work }(\mathrm{S}+\mathrm{HH})\end{array}$ & $\begin{array}{l}\text { Problems with } \\
\text { ADL }\end{array}$ & $\begin{array}{l}\text { Alternative } \\
\text { health care }\end{array}$ \\
\hline Gender & $\begin{array}{l}\text { BMI } \\
\text { (calculated } \\
\text { from self- } \\
\text { reported } \\
\text { weight and } \\
\text { height) }\end{array}$ & $\begin{array}{l}\text { Receives social benefit } \\
(\mathrm{S}+\mathrm{HH})\end{array}$ & $\begin{array}{l}\text { Long-standing } \\
\text { illness }\end{array}$ & $\begin{array}{l}\text { Use of OTC } \\
\text { drugs during } \\
\text { last } 2 \text { weeks }\end{array}$ \\
\hline Education $(\mathrm{S}+\mathrm{HH})$ & $\begin{array}{l}\text { Weight (self- } \\
\text { reported) }\end{array}$ & $\begin{array}{l}\text { Occupational class } \\
(\mathrm{S}+\mathrm{HH})\end{array}$ & $\begin{array}{l}\text { Limiting } \\
\text { longstanding } \\
\text { illness }\end{array}$ & $\begin{array}{l}\text { Type of ОTC } \\
\text { drugs }\end{array}$ \\
\hline Type of household & $\begin{array}{l}\text { Height (self- } \\
\text { reported) }\end{array}$ & $\begin{array}{l}\text { Shift/evening/weekend } \\
\text { work }\end{array}$ & Diabetes & $\begin{array}{l}\text { Use of } \\
\text { prescribed } \\
\text { drugs during } \\
\text { last } 2 \text { weeks }\end{array}$ \\
\hline $\begin{array}{l}\text { Number of persons } \\
\text { in household }\end{array}$ & Alcohol use & Heavy work & $\begin{array}{l}\text { Self-perceived } \\
\text { health }\end{array}$ & $\begin{array}{l}\text { Type of } \\
\text { prescribed } \\
\text { drugs }\end{array}$ \\
\hline Household income & $\begin{array}{l}\text { Hours doing } \\
\text { sport per } \\
\text { week }\end{array}$ & Noise exposure at work & Satisfied with life & $\begin{array}{l}\text { Visited } \\
\text { specialist in } \\
\text { last } 2 \text { months }\end{array}$ \\
\hline Marital status & $\begin{array}{l}\text { Hours cycling } \\
\text { per week }\end{array}$ & Stress at work & Happiness & $\begin{array}{l}\text { Type of } \\
\text { specialist } \\
\text { visited }\end{array}$ \\
\hline Nationality & $\begin{array}{l}\text { Hours } \\
\text { walking per } \\
\text { week }\end{array}$ & Has disability pension & & $\begin{array}{l}\text { Visited general } \\
\text { practitioner in } \\
\text { last } 2 \text { weeks }\end{array}$ \\
\hline $\begin{array}{l}\text { Type of health } \\
\text { insurance }\end{array}$ & & $\begin{array}{l}\mathrm{S} \text { is main wage earner } \\
(=\text { highest income })\end{array}$ & & $\begin{array}{l}\text { General } \\
\text { practitioner } \\
\text { prescribes } \\
\text { alternative } \\
\text { treatments }\end{array}$ \\
\hline $\begin{array}{l}\text { Month of HIS } \\
\text { participation }\end{array}$ & & & & $\begin{array}{l}\text { Nights in } \\
\text { hospital in last } \\
\text { year }\end{array}$ \\
\hline \multirow[t]{2}{*}{ Religion } & & & & $\begin{array}{l}\text { Sickness leave } \\
\text { in last } 2 \\
\text { months }\end{array}$ \\
\hline & & & & $\begin{array}{l}\text { Uses mental } \\
\text { health care }\end{array}$ \\
\hline
\end{tabular}

$\mathrm{S}$, subject; $\mathrm{HH}$, head of household (person in household who earns the highest wage); ADL, activities of daily living; OTC, over the counter; HIS, health interview survey; BMI, body mass index.

In order to use all available information and to prevent further bias (e.g. caused by selective refusal to answer the question on income), the authors dealt with item non-response in the HIS by multiple imputation, ${ }^{16}$ carried out with an adapted version of predictive mean matching ${ }^{17}$ with a SAS macro making partial use of SAS PROC MI. The macro can be obtained from the authors. Multiple imputations yielded five versions of the datasets, in which the non-missing data are the same but the values imputed for the missing data vary from dataset to dataset. Analyses were performed five times, and the results were pooled using methods yielding valid confidence intervals (taking the uncertainty due to missing data into account). 
To describe the determinants of non-participation in the HES by HIS responders, logistic regression was used with participation as the dependent variable. Stepwise backward selection was used, pooling the parameter values of the five imputed datasets after each selection step. The pool of variables contained all variables derived from Table 1, fractional polynomial terms for age, and interaction terms between gender and these polynomial age terms. After a first selection step using $P>0.05$ as the criterion for removal, interaction terms were added between all the remaining variables, and the selection procedure was repeated with this set and $P>0.01$ as criterion. $P>0.01$ was used rather than $P>0.05$ as the final criterion in order to reduce the number of false-positive findings. If an interaction term was retained, its component terms were added to the model to improve interpretability. The indicator variable 'holds paid job' was also forced into the model to improve interpretation because many variables are only applicable to those who work (e.g. stress at work, type of occupation, number of hours worked). With the indicator variable in the model, the odds ratio for, for example, hours worked can be interpreted as the odds ratio of an extra hour worked within the group of those holding jobs.

To quantify bias in the outcomes, the average outcome values (blood pressure, weight, height, total and HDL cholesterol, and fasting glucose) were predicted in HES non-participants. The prediction model (a linear regression model) was fit on the HES participants, using different covariates for each outcome. Model selection was carried out using backward selection, pooling the parameter values of the five imputed datasets after each selection step and using the pooled parameter values from the last step to predict the outcome values. Cross-validation was used to determine which $P$ value for removal gave the best predictions. The pool of variables from which to select the model contained fractional polynomial terms for age and self-reported body weight, as well as interaction terms between gender and the polynomial age terms.

The pool of variables for predicting height and weight also contained fractional polynomial terms of self-reported body height; for predicting the other outcomes, the pool contained fractional polynomial terms of self-reported body mass index. Both crude average outcomes and age-standardized, sex-specific average outcomes were compared between HES participants and HES non-participants.

The magnitude of bias in associations between variables due to non-response may be small even if there is bias in the prevalence of averages of the individual variables. This bias in associations was studied by comparing associations between HIS variables in the entire HIS population with those associations in HES participants alone. For this analysis, three 'exposure' HIS variables and three 'outcome' HIS variables that were strongly associated with non-participation were selected in order to represent the worst-case scenarios. 


\section{Results}

\section{Determinants of non-participation}

Figure 1 shows that the rate of participation increased gradually with age until approximately 60 years of age, and decreased strongly with age thereafter. There was some interaction with gender, which disappeared after inclusion of other covariates.

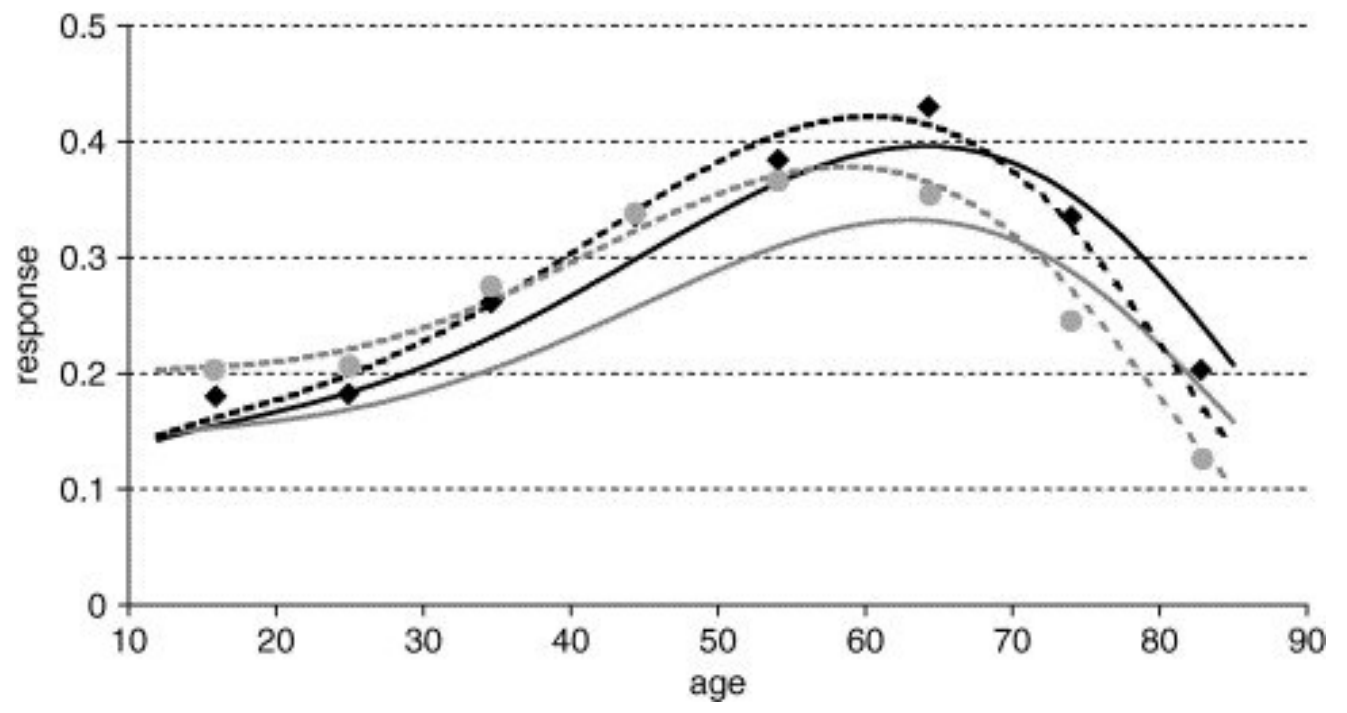

Figure 1. Participation rates in the health examination survey among eligible health interview survey respondents by age and gender. Diamonds, crude rate for men; circles, crude rate for women; broken line, fitted values (unadjusted); solid line, fitted values adjusted for all variables in Table 2; black, men; grey, women.

Table 2 shows the variables that were significantly related to non-response after adjusting for all other variables related to non-response. Although this table includes many variables, many more are not included as they were not associated with non-response. The table shows that socio-economic variables are important determinants of HES participation, with those from lower socio-economic strata having lower participation rates. When adjusting for all other variables, including occupation and income, differences in participation rates are only seen for those with either a very high or a very low educational level. People without paid work were less likely to participate than those with a part-time job, but of those with a job, the participation rate decreased with the number of hours worked. The results of the multivariate analysis imply that, other things (including health) being equal, those working in unskilled work or working for at least $22 \mathrm{~h} /$ week in skilled work were less likely to participate than those without a job. Women, Muslims and people living in rural areas were less likely to participate, while those from the western part of the country (where the large cities are located) were more likely to participate. 
Table 2.

Health examination survey (HES) participation rates among eligible health interview survey (HIS) participants, and multivariate odds ratio (adjusted for all other variables in the table and age) of participating in the HES.

\begin{tabular}{|c|c|c|c|c|c|}
\hline Crude variable & Level & $n$ & $\begin{array}{l}\text { Participation } \\
\text { rate }(\%)\end{array}$ & $\begin{array}{l}\text { Model } \\
\text { category }\end{array}$ & $\begin{array}{l}\text { Adjusted odds } \\
\text { ratios of } \\
\text { participating }\end{array}$ \\
\hline All & All & 12,786 & 28.9 & & \\
\hline \multirow[t]{2}{*}{ Gender } & Male & 6235 & 29.5 & Male & 1.00 \\
\hline & Female & 6551 & 28.4 & Female & $0.82[0.75-0.90]$ \\
\hline \multirow[t]{3}{*}{ Type of occupation } & Skilled work ${ }^{a}$ & 4963 & 31.6 & Skilled $^{\mathrm{a}}$ & 1.00 (reference) \\
\hline & Unskilled work & 2702 & 24.6 & Unskilled & $0.76[0.67-0.88]$ \\
\hline & $\begin{array}{l}\text { Occupational } \\
\text { status }\end{array}$ & & & & \\
\hline \multirow[t]{2}{*}{$\begin{array}{l}\text { Occupational } \\
\text { status }\end{array}$} & In work force & 7665 & 29.1 & In workforce & 1.00 \\
\hline & $\begin{array}{l}\text { Not in } \\
\text { workforce }\end{array}$ & 5121 & 28.6 & $\begin{array}{l}\text { Not in } \\
\text { workforce }\end{array}$ & $0.83[0.71-0.97]$ \\
\hline \multirow[t]{6}{*}{$\begin{array}{l}\text { Number of hours } \\
\text { worked per week }\end{array}$} & $\begin{array}{l}\text { Not in } \\
\text { workforce }\end{array}$ & 5121 & 28.6 & $\begin{array}{l}\text { Per } 10 \mathrm{~h} \\
\text { worked (only } \\
\text { when working) }\end{array}$ & $0.87[0.83-0.91]$ \\
\hline & $1-4$ & 203 & 33.5 & & \\
\hline & $5-12$ & 727 & 26.1 & & \\
\hline & $13-29$ & 1623 & 32.8 & & \\
\hline & $30-39$ & 2162 & 30.8 & & \\
\hline & 40 or more & 2950 & 26.4 & & \\
\hline \multirow[t]{2}{*}{ Religion } & Muslim & 294 & 9.9 & Muslim & $0.57[0.38-0.86]$ \\
\hline & Other/none & 12,492 & 29.4 & Other/none & 1.00 \\
\hline \multirow[t]{6}{*}{ Educational level } & $\begin{array}{l}\text { Primary } \\
\text { education }\end{array}$ & 2904 & 21.7 & $\begin{array}{l}\text { Primary } \\
\text { education }\end{array}$ & $0.81[0.71-0.92]$ \\
\hline & $\begin{array}{l}3 \text { years of } \\
\text { secondary } \\
\text { education }\end{array}$ & 3375 & 28.8 & $\begin{array}{l}3 \text { years of } \\
\text { secondary } \\
\text { education }\end{array}$ & $0.96[0.86-1.07]$ \\
\hline & High school & 4079 & 30.7 & High school & 1.00 \\
\hline & $\begin{array}{l}\text { Bachelor's } \\
\text { degree }\end{array}$ & 1713 & 35.0 & Bachelor & $1.01[0.89-1.14]$ \\
\hline & $\begin{array}{l}\text { Master's } \\
\text { degree }\end{array}$ & 626 & 35.5 & Master & $0.97[0.80-1.17]$ \\
\hline & $\mathrm{PhD}$ & 88 & 24.0 & $\mathrm{Ph} D$ & $0.55[0.33-0.92]$ \\
\hline \multirow[t]{10}{*}{$\begin{array}{l}\text { Decile of } \\
\text { household income }\end{array}$} & $\begin{array}{l}\text { 10th (highest } \\
\text { income) }\end{array}$ & 1258 & 32.4 & $\begin{array}{l}\text { Highest vs } \\
\text { lowest decile } \\
\text { inc: }^{\text {c }}\end{array}$ & \\
\hline & 9th & 1230 & 32.6 & & \\
\hline & 8th & 1256 & 30.9 & $\begin{array}{l}\text { Those who do } \\
\text { not participate } \\
\text { in sports }\end{array}$ & $1.64[1.33-2.01]$ \\
\hline & 7th & 1275 & 30.0 & $\begin{array}{l}\text { Those who } \\
\text { participate in } \\
\text { sports }\end{array}$ & $1.02[0.41-2.54]$ \\
\hline & 6th & 1296 & 31.5 & & \\
\hline & 5th & 1205 & 29.4 & & \\
\hline & 4th & 1325 & 28.7 & & \\
\hline & $3 r d$ & 1387 & 27.5 & & \\
\hline & 2nd & 1244 & 25.0 & & \\
\hline & $1 \mathrm{st}$ & 1310 & 21.7 & & \\
\hline \multirow[t]{5}{*}{ Urbanity } & Very strong & 1539 & 30.2 & Very strong & $0.98[0.85-1.13]$ \\
\hline & Strong & 3857 & 31.5 & Strong & 1.00 \\
\hline & Moderate & 2889 & 28.8 & Moderate & $0.83[0.74-0.93]$ \\
\hline & Little & 2797 & 26.7 & Little & $0.75[0.67-0.85]$ \\
\hline & None & 1704 & 25.9 & None & $0.74[0.65-0.85]$ \\
\hline Region & Western part & 4925 & 31.4 & Western part & $1.15[1.05-1.25]$ \\
\hline
\end{tabular}


Public Health Volume 120, Issue 4 , April 2006, Pages 297-308

\begin{tabular}{|c|c|c|c|c|c|}
\hline Crude variable & Level & $n$ & $\begin{array}{l}\text { Participation } \\
\text { rate }(\%)\end{array}$ & $\begin{array}{l}\text { Model } \\
\text { category }\end{array}$ & $\begin{array}{l}\text { Adjusted odds } \\
\text { ratios of } \\
\text { participating }\end{array}$ \\
\hline & Other & 7861 & 27.4 & Other & 1.00 \\
\hline \multirow[t]{2}{*}{$\begin{array}{l}\text { Long-term health } \\
\text { condition }\end{array}$} & No & 8369 & 28.0 & No & 1.00 \\
\hline & Yes & 4417 & 30.6 & Yes & $0.87[0.79-0.97]$ \\
\hline \multirow[t]{4}{*}{$\begin{array}{l}\text { ADL (only } \\
\text { available for age } \\
>54 \text { years) }\end{array}$} & Age $<55$ years & 9294 & 27.1 & $\begin{array}{l}\text { Odds ratio per } \\
\text { extra ADL } \\
\text { point }\end{array}$ & $0.94[0.91-0.98]$ \\
\hline & No problems & 2396 & 37.4 & & \\
\hline & Score 1-2 & 497 & 30.6 & & \\
\hline & Score 3+ & 599 & 21.7 & & \\
\hline \multirow[t]{5}{*}{ Self-rated health } & Very good & 2755 & 30.1 & Very good & $1.09[0.98-1.21]$ \\
\hline & Good & 7097 & 29.4 & Good & 1.00 \\
\hline & Reasonable & 1722 & 28.0 & Reasonable & $0.85[0.74-0.97]$ \\
\hline & $\begin{array}{l}\text { Sometimes } \\
\text { good, } \\
\text { sometimes bad }\end{array}$ & 866 & 27.0 & $\begin{array}{l}\text { Sometimes } \\
\text { good, } \\
\text { sometimes } \\
\text { bad }\end{array}$ & $0.87[0.73-1.05]$ \\
\hline & Bad & 346 & 18.8 & Bad & $0.59[0.43-0.81]$ \\
\hline \multirow[t]{4}{*}{$\begin{array}{l}\text { Last visit to } \\
\text { medical specialist }\end{array}$} & $<2$ months ago & 2089 & 29.7 & $\begin{array}{l}<2 \text { months } \\
\text { ago }\end{array}$ & $1.03[0.91-1.17]$ \\
\hline & $\begin{array}{l}\text { 2-12 months } \\
\text { ago }\end{array}$ & 3067 & 31.0 & $\begin{array}{l}2-12 \text { months } \\
\text { ago }\end{array}$ & $1.05[0.95-1.17]$ \\
\hline & $\begin{array}{l}>12 \text { months } \\
\text { ago }\end{array}$ & 6690 & 29.2 & $\begin{array}{l}>12 \text { months } \\
\text { ago }\end{array}$ & 1.00 \\
\hline & $\begin{array}{l}\text { Never visited a } \\
\text { medical } \\
\text { specialist }\end{array}$ & 940 & 18.5 & $\begin{array}{l}\text { Never visited a } \\
\text { medical } \\
\text { specialist }\end{array}$ & $0.76[0.63-0.91]$ \\
\hline \multirow[t]{2}{*}{$\begin{array}{l}\text { Visit to internist in } \\
\text { last } 2 \text { months }\end{array}$} & Yes & 257 & 23.7 & Yes & $0.66[0.48-0.91]$ \\
\hline & No & 12,529 & 29.0 & No & 1.00 \\
\hline \multirow[t]{4}{*}{ Last visit to GP } & $<2$ months ago & 4708 & 30.5 & $\begin{array}{l}<2 \text { months } \\
\text { ago }\end{array}$ & $1.23[1.09-1.39]$ \\
\hline & $\begin{array}{l}2-12 \text { months } \\
\text { ago }\end{array}$ & 5169 & 29.1 & $\begin{array}{l}2-12 \text { months } \\
\text { ago }\end{array}$ & $1.13[1.01-1.27]$ \\
\hline & $\begin{array}{l}>12 \text { months } \\
\text { ago }\end{array}$ & 2884 & 26.3 & $\begin{array}{l}>12 \text { months } \\
\text { ago }\end{array}$ & 1.00 \\
\hline & $\begin{array}{l}\text { Never visited a } \\
\text { GP }\end{array}$ & 25 & 4.0 & $\begin{array}{l}\text { Never visited a } \\
\text { GP }\end{array}$ & $0.14[0.02-1.10]$ \\
\hline \multirow{2}{*}{$\begin{array}{l}\text { Visited alternative } \\
\text { medical } \\
\text { practitioner in last } \\
12 \text { months }\end{array}$} & No & 11,951 & 28.5 & No & 1.00 \\
\hline & Yes & 835 & 35.7 & Yes & 1.25 [1.07-1.47] \\
\hline \multirow[t]{2}{*}{$\begin{array}{l}\text { Sports } \\
\text { participation }\end{array}$} & No & 5919 & 25.7 & $\begin{array}{l}\text { In lowest } \\
\text { income }\end{array}$ & $1.73[0.69-4.3]$ \\
\hline & Yes & 6867 & 31.7 & $\begin{array}{l}\text { In highest } \\
\text { income }\end{array}$ & $1.08[0.95-1.22]$ \\
\hline \multirow[t]{2}{*}{$\begin{array}{l}\text { Returned self- } \\
\text { administered HIS } \\
\text { questionnaire }\end{array}$} & Yes & 9547 & 34.8 & Yes & 1.00 \\
\hline & No & 3239 & 11.7 & No & $0.29[0.25-0.32]$ \\
\hline
\end{tabular}

$A D L$, activities of daily living; GP, general practitioner.

${ }^{a}$ Including the self-employed.

${ }^{b}$ Calculated from quadratic variable in model.

${ }^{c}$ Due to significant interaction between income and doing sport, odds ratios are calculated within strata of the other variable. 
The relationship between health and participation rates is complex. Generally, those who used more health care (more frequent visits to general practitioners, medical specialists, alternative medical practitioners) were likely to participate in the HES, while those with better health (as measured by self-perceived health status and the absence of longstanding illness) were also likely to participate, leading to an overrepresentation of the 'worried well' (i.e. healthy people with frequent healthcare use). However, those who had visited an internist during the previous 2 months did not fit this pattern, as they were less likely to participate. This may indicate that visiting an internist (which is only possible after referral by a general practitioner in the Dutch healthcare system) reflects worse health rather than a tendency to use healthcare services more frequently.

Large differences in participation rates were seen between those who did and those who did not return the mail-back questionnaire that was part of the HIS.

\section{Biases in outcomes to be monitored}

Table 3 shows the strongest predictors for the seven outcomes in this study. As the prediction model contained many predictors, only the strongest predictors are shown. The percentage of variance explained by the prediction models was high (>90\%) for height and weight (not surprising as self-reported height and weight were among the predictors), intermediate for systolic blood pressure (45\%), and moderate for the other variables (24-29\%).

Table 3.

Predictors with $P<0.001$ in the models for health examination survey (HES) outcomes; all predictors are based on self-reported data from the health interview survey (HIS).

\begin{tabular}{|c|c|c|}
\hline HES outcome & Predictors with $P<0.001$ & $\begin{array}{l}\text { Variance } \\
\text { predicted by the } \\
\text { model }(\%)\end{array}$ \\
\hline Total cholesterol & $\begin{array}{l}\text { Age, interaction age and gender, gender, BMI, diabetes, } \\
\text { number of persons in the household, height }{ }^{\mathrm{a}}\end{array}$ & 25.7 \\
\hline $\begin{array}{l}\text { High-density } \\
\text { lipoprotein } \\
\text { cholesterol }\end{array}$ & $\begin{array}{l}\text { Gender, weight, alcohol on week days (number of glasses), } \\
\text { frequency of alcohol use, height }{ }^{\mathrm{a}} \text {, number of cigarettes } \\
\text { smoked, interaction between gender and age, age }\end{array}$ & 27.8 \\
\hline Fasting glucose & $\begin{array}{l}\text { Diabetes, weight }{ }^{\mathrm{a}} \text {, height }{ }^{\mathrm{a}}, \mathrm{BMI}^{\mathrm{b}} \text {, age, gender, 'other' living } \\
\text { arrangement (not with family/partner/children or alone) }\end{array}$ & 23.9 \\
\hline $\begin{array}{l}\text { Diastolic blood } \\
\text { pressure }\end{array}$ & Age, ever smoker, alcohol on week days (number of glasses) & 28.6 \\
\hline $\begin{array}{l}\text { Systolic blood } \\
\text { pressure }\end{array}$ & Age, BMI ${ }^{\mathrm{b}}$, height ${ }^{\mathrm{a}}$ & 44.5 \\
\hline Body height & Height $^{\mathrm{a}}$, educational level, age, $\mathrm{BMI}^{\mathrm{b}}$ & 91.2 \\
\hline Body weight & Weight $^{a}$, age & 92.1 \\
\hline
\end{tabular}

BMI, body mass index.

${ }^{a}$ As self-reported in the HIS interview.

${ }^{b}$ Calculated from self-reported height and weight in the HIS.

Table 4 compares the average value of the seven outcomes as measured in the HES participants with the predicted value in non-participants. Crude predicted values for the general population were lower than the lower boundary of the $95 \%$ confidence interval of the HES average for three of the five outcomes (blood pressure, cholesterol and body weight). 
Table 4.

Outcomes in all health examination survey (HES) respondents, population SD in HES responders, and predicted outcomes in all health interview survey (HIS) responders eligible for HES participation who did not participate.

\begin{tabular}{|l|l|l|l|}
\hline & $\begin{array}{l}\text { Mean value measured in } \\
\text { HES [95\% CI] }\end{array}$ & $\begin{array}{l}\text { Population SD } \\
\text { in HES }\end{array}$ & $\begin{array}{l}\text { Predicted in HES non- } \\
\text { responders }^{\mathbf{a}}\end{array}$ \\
\hline Total cholesterol & $5.26[5.23-5.30]$ & 1.08 & 5.12 \\
\hline $\begin{array}{l}\text { High-density } \\
\text { lipoprotein cholesterol }\end{array}$ & $1.25[1.24-1.26]$ & 0.34 & 1.23 \\
\hline Fasting glucose & $4.81[4.77-4.85]$ & 1.00 & 4.79 \\
\hline $\begin{array}{l}\text { Diastolic blood } \\
\text { pressure }\end{array}$ & $81.6[81.2-82.0]$ & 11.2 & 79.8 \\
\hline Systolic blood pressure & $130.4[129.7-131.1]$ & 21.8 & 128.3 \\
\hline Body height & $172.8[172.5-173.1]$ & 9.4 & 172.5 \\
\hline Body weight & $75.2[74.7-75.7]$ & 14.5 & 73.8 \\
\hline
\end{tabular}

CI, confidence intervals; SD, standard deviation.

a Using the outcome model described in Table 3.

However, age-standardized and sex-specific figures are more relevant in practical situations (Table 5). Here most estimates are within the $95 \%$ confidence intervals of the HES measurements, with the exception of body height in men (higher in participants) and HDL-cholesterol (higher in participants), fasting glucose levels (lower in participants) and body weight in women (lower in participants), indicating that the differences in Table 4 reflect that participants and nonparticipants differ in age and gender.

Table 5.

Age-standardized outcomes in health examination survey (HES) participants compared with predicted outcomes in non-participants.

\begin{tabular}{|l|l|l|l|l|}
\hline & Men & Women \\
\hline & $\begin{array}{l}\text { HES } \\
\text { participants }\end{array}$ & $\begin{array}{l}\text { HES non- } \\
\text { participants }\end{array}$ & $\begin{array}{l}\text { HES } \\
\text { participants }\end{array}$ & $\begin{array}{l}\text { HES non- } \\
\text { participants }\end{array}$ \\
\hline Total cholesterol & $\begin{array}{l}5.10[5.05- \\
5.15]\end{array}$ & 5.11 & $\begin{array}{l}5.17[5.12- \\
5.23]\end{array}$ & 5.19 \\
\hline $\begin{array}{l}\text { High-density } \\
\text { lipoprotein cholesterol }\end{array}$ & $\begin{array}{l}1.12[1.10- \\
1.13]\end{array}$ & 1.10 & $\begin{array}{l}1.37[1.36- \\
1.39]\end{array}$ & 1.35 \\
\hline Fasting glucose & $\begin{array}{l}4.88[4.83- \\
4.94]\end{array}$ & 4.92 & $\begin{array}{l}4.64[4.58- \\
4.69]\end{array}$ & 4.70 \\
\hline $\begin{array}{l}\text { Diastolic blood } \\
\text { pressure }\end{array}$ & $\begin{array}{l}80.8[80.3- \\
81.4]\end{array}$ & 80.7 & $\begin{array}{l}79.4[79.0- \\
80.0]\end{array}$ & 79.7 \\
\hline $\begin{array}{l}\text { Systolic blood } \\
\text { pressure }\end{array}$ & $\begin{array}{l}132.0[131.0- \\
133.0]\end{array}$ & 131.8 & $\begin{array}{l}125.4[124.5- \\
126.4]\end{array}$ & 125.7 \\
\hline Body height & $\begin{array}{l}179.4[179.0- \\
179.7]\end{array}$ & 178.7 & $\begin{array}{l}166.6[166.3- \\
167.0]\end{array}$ & 166.3 \\
\hline Body weight & $\begin{array}{l}80.0[79.4- \\
80.7]\end{array}$ & 79.4 & $\begin{array}{l}67.9[67.3- \\
68.5]\end{array}$ & 68.9 \\
\hline
\end{tabular}

\section{Biases in associations between variables}

The odds ratios for the associations between some HIS variables that are heavily influenced by non-participation were compared between analyses in all HIS participants and in HES participants alone (Table 6). This table shows that the $95 \%$ confidence intervals of the odds ratios calculated using HES participants 
alone largely overlap those calculated using the entire HIS population, so no clear bias seems to result from non-participation.

Table 6.

Odds ratios between outcomes subject to selective non-response [having poor health, a longstanding illness, or having visited a general practioner (GP) in the last 2 months] and several factors also subject to selective non-response.

\begin{tabular}{|c|c|c|c|c|c|c|}
\hline & \multicolumn{2}{|c|}{$\begin{array}{l}\text { Poor self-perceived } \\
\text { health }\end{array}$} & \multicolumn{2}{|c|}{ Longstanding illness } & \multicolumn{2}{|c|}{$\begin{array}{l}\text { Visit to general } \\
\text { practitioner in last } 2 \\
\text { months }\end{array}$} \\
\hline & $\begin{array}{l}\text { HIS } \\
(n=12 \\
786)\end{array}$ & $\begin{array}{l}\text { HES } \\
(n=3699)\end{array}$ & $\begin{array}{l}\text { HIS } \\
(n=12 \\
786)\end{array}$ & $\begin{array}{l}\text { HES } \\
(n=3699)\end{array}$ & $\begin{array}{l}\text { HIS } \\
(n=12 \\
786)\end{array}$ & $\begin{array}{l}\text { HES } \\
(n=3699)\end{array}$ \\
\hline \multicolumn{7}{|l|}{ Occupation } \\
\hline Unskilled work & $\begin{array}{l}2.13 \\
{[1.28-} \\
3.54]\end{array}$ & $\begin{array}{l}2.21[0.74- \\
6.57]\end{array}$ & $\begin{array}{l}1.28 \\
{[1.15-} \\
1.44]\end{array}$ & $\begin{array}{l}1.23[1.00- \\
1.52]\end{array}$ & $\begin{array}{l}1.20 \\
{[1.07-} \\
1.32]\end{array}$ & $\begin{array}{l}1.22[1.00- \\
1.50]\end{array}$ \\
\hline \multicolumn{7}{|l|}{ Educational level } \\
\hline $\begin{array}{l}\text { Primary } \\
\text { education }\end{array}$ & $\begin{array}{l}2.76 \\
{[2.04-} \\
3.73]\end{array}$ & $\begin{array}{l}3.80[1.82- \\
7.92]\end{array}$ & $\begin{array}{l}1.61 \\
{[1.43-} \\
1.80]\end{array}$ & $\begin{array}{l}1.56[1.26- \\
1.95]\end{array}$ & $\begin{array}{l}1.42 \\
{[1.26-} \\
1.58]\end{array}$ & $\begin{array}{l}1.34[1.08- \\
1.67]\end{array}$ \\
\hline $\begin{array}{l}3 \text { years of } \\
\text { secondary } \\
\text { education }\end{array}$ & $\begin{array}{l}1.20 \\
{[0.86-} \\
1.66]\end{array}$ & $\begin{array}{l}2.03[0.97- \\
4.24]\end{array}$ & $\begin{array}{l}1.12 \\
{[1.01-} \\
1.24]\end{array}$ & $\begin{array}{l}1.25[1.04- \\
1.49]\end{array}$ & $\begin{array}{l}1.14 \\
{[1.03-} \\
1.26]\end{array}$ & $\begin{array}{l}1.19[0.99- \\
1.42]\end{array}$ \\
\hline High school & 1.00 & 1.00 & 1.00 & 1.00 & 1.00 & 1.00 \\
\hline Bachelor's degree & $\begin{array}{l}0.82 \\
{[0.53-} \\
1.27]\end{array}$ & $\begin{array}{l}1.15[0.45- \\
2.96]\end{array}$ & $\begin{array}{l}0.88 \\
{[0.77-} \\
0.99]\end{array}$ & $\begin{array}{l}0.95[0.77- \\
1.18]\end{array}$ & $\begin{array}{l}1.00 \\
{[0.88-} \\
1.12]\end{array}$ & $\begin{array}{l}1.07 \text { [0.87- } \\
1.31]\end{array}$ \\
\hline $\begin{array}{l}\text { Master's } \\
\text { degree/PhD }\end{array}$ & $\begin{array}{l}0.67 \\
{[0.35-} \\
1.31] \\
\end{array}$ & $\begin{array}{l}1.13[0.31- \\
4.06]\end{array}$ & $\begin{array}{l}0.79 \\
{[0.66-} \\
0.95]\end{array}$ & $\begin{array}{l}0.82[0.61- \\
1.12]\end{array}$ & $\begin{array}{l}0.97 \\
{[0.82-} \\
1.16]\end{array}$ & $\begin{array}{l}0.98[0.73- \\
1.31]\end{array}$ \\
\hline \multicolumn{7}{|l|}{ Urbanity } \\
\hline Very strong & $\begin{array}{l}1.40 \\
{[1.02-} \\
1.92]\end{array}$ & $\begin{array}{l}1.74[0.90- \\
3.37]\end{array}$ & $\begin{array}{l}1.02 \\
{[0.90-} \\
1.16]\end{array}$ & $\begin{array}{l}0.96[0.76- \\
1.20]\end{array}$ & $\begin{array}{l}1.03 \\
{[0.91-} \\
1.16]\end{array}$ & $\begin{array}{l}1.00[0.80- \\
1.25]\end{array}$ \\
\hline Strong & 1.00 & 1.00 & 1.00 & 1.00 & 1.00 & 1.00 \\
\hline Moderate & $\begin{array}{l}0.69 \\
{[0.50-} \\
0.95]\end{array}$ & $\begin{array}{l}0.51[0.23- \\
1.10]\end{array}$ & $\begin{array}{l}0.92 \\
{[0.83-} \\
1.02]\end{array}$ & $\begin{array}{l}0.84[0.69- \\
1.01]\end{array}$ & $\begin{array}{l}1.02 \\
{[0.92-} \\
1.13]\end{array}$ & $\begin{array}{l}1.00[0.83- \\
1.20]\end{array}$ \\
\hline Little & $\begin{array}{l}0.71 \\
{[0.51-} \\
0.97]\end{array}$ & $\begin{array}{l}0.62[0.29- \\
1.31]\end{array}$ & $\begin{array}{l}0.92 \\
{[0.83-} \\
1.03]\end{array}$ & $\begin{array}{l}0.86[0.71- \\
1.04]\end{array}$ & $\begin{array}{l}0.90 \\
{[0.81-} \\
1.00]\end{array}$ & $\begin{array}{l}0.80[0.66- \\
0.97]\end{array}$ \\
\hline None & $\begin{array}{l}0.94 \\
{[0.66-} \\
1.32]\end{array}$ & $\begin{array}{l}0.72[0.31- \\
1.69]\end{array}$ & $\begin{array}{l}0.90 \\
{[0.79-} \\
1.02]\end{array}$ & $\begin{array}{l}1.00[0.79- \\
1.26]\end{array}$ & $\begin{array}{l}0.91 \\
{[0.80-} \\
1.02]\end{array}$ & $\begin{array}{l}1.00[0.80- \\
1.26]\end{array}$ \\
\hline $\begin{array}{l}\text { Longstanding } \\
\text { illness }\end{array}$ & & & & & $\begin{array}{l}2.51 \\
{[2.32-} \\
2.72] \\
\end{array}$ & $\begin{array}{l}2.21[1.92- \\
2.55]\end{array}$ \\
\hline $\begin{array}{l}\text { Poor self-rated } \\
\text { health }\end{array}$ & & & & & $\begin{array}{l}4.30 \\
{[3.36-} \\
5.50]\end{array}$ & $\begin{array}{l}5.61[2.08- \\
10.2]\end{array}$ \\
\hline
\end{tabular}

A comparison between odds ratios in the entire population participating in the health interview survey (HIS) and in those participating in the health examination survey (HES) alone. 


\section{Discussion}

This study found that HES participants differed from non-participants in many aspects. Most notable was that participants had a higher socio-economic status and were more likely to be 'worried well'. Analysis of the biases caused by this selective participation found that it does not generally lead to large biases in prevalence figures, and it has little influence on the relationship between variables.

Initially, the variables determining participation in a second-step examination (HES) by those who had participated in the first step (HIS) were investigated. As hardcore non-responders are not present in the HIS sample, the mechanisms of non-participation in a second-step examination may differ from the mechanisms of initial non-participation. However, most of the results indicate that the mechanisms are not very different from those in non-response in the first step. As in most non-response studies looking at initial non-response, people from a higher socio-economic strata were more likely to participate, as were the 'worried well', characterized by using more healthcare services, ${ }^{10,11}$ and 18 being healthier, ${ }^{19}$, 20,21 and 22 and following a healthier lifestyle. ${ }^{23,} 24$ and 25 However, the latter aspect (healthier lifestyle) was only partially observed in the present study; participation in sports only made a difference for subjects with a low income, while smoking did not influence participation rates at all.

Another difference from previous findings is the lower participation rate observed in rural areas, where surveys usually observe higher rates of response. ${ }^{26}$ and 27 This may be due to the longer distance to travel to the examination centre in rural areas. Participation in the NHANES physical examination was observed to be higher in those living near the location of the examination. ${ }^{12}$

People who did not return the self-administered questionnaire of the HIS participated much less frequently in the HES. A similar finding has been observed previously for those who returned a questionnaire only after receiving a reminder; they were considerably less likely to respond to a questionnaire sent 11 years later. ${ }^{28}$ This supports the notion of a general tendency to respond as postulated in the 'continuum of resistance' theory. ${ }^{29}$ and 30 According to this theory, the more resistant a subject is to participation, the more he/she resembles people who never respond. An non-testable sequitur of this theory is that the difference between respondents who are 'easy' and 'hard' to recruit can be extrapolated to predict how non-responders would have reacted, and statistical methods have been developed that perform such an extrapolation. ${ }^{31}$ In the present case, this theory implies that a lack of bias in outcomes due to the selective response of HES participants within the HIS sample indicates that there is also no bias due to selective non-response of HIS responders within the general population. This theory, however, remains to be verified.

The authors also looked at the magnitude of the bias due to selective nonresponse in the population average values of the main outcomes. Although nonparticipation rates were high in this study and depended on socio-economic position and health status (over-representation of the 'worried well'), bias could not be demonstrated for age-standardized and sex-specific average outcomes, except for body height in men and HDL cholesterol, fasting glucose and body weight in women. This is probably due to a lack of concordance in the variables explaining non-response (health status and socio-economic position, see Table 2) and those predicting the outcomes (Table 3 ). Apart from age and gender, only education was strongly related to both non-response and one outcome (body 
height). Based on this lack of two-way associations, it was anticipated that no substantial bias could be detected with the variables available in this study.

This is particularly true for outcomes for which the models predicted less than $30 \%$ of the variance in outcomes, indicating that the HIS variables are only weakly related to the outcomes. If other variables (not included in the HIS) exist that are related to both participation and an outcome, this would result in bias not picked up by the modelling. One example would be dietary habits, which influence serum cholesterol levels. It has been observed previously that those using margarine and skimmed milk were more likely to consent to clinical examination. ${ }^{13}$ Apart from a lack of dietary information, the HIS covered a large range of health-related topics and socio-economic information, so most other important areas were probably included in the present analyses. Height and weight could be predicted accurately and therefore, their prediction is unlikely to be biased by omitted predictors. For the variables that were predicted accurately, a bias was only observed for body weight in women and body height in men.

The differences observed between HES participants and non-participants are probably related to the under-representation of participants with lower socioeconomic status in the HES. An earlier survey in The Netherlands looking at the relationship between socio-economic status and blood pressure, cholesterol and overweight showed that the relative index of inequality was only above five for overweight and HDL-cholesterol in women; the same two factors for which bias was observed in women in the present study. The relative index of inequality for these factors was clearly lower in men, and was even lower for blood pressure and total cholesterol in both men and women. ${ }^{32}$

Another explanation for the lack of bias in outcomes could be that non-responders are a mixture of groups with their own reasons for not participating. As these reasons may be connected to health outcomes in different ways, their influences could partially cancel each other out.

These results are largely similar to those of an earlier study on non-response on a questionnaire following a health examination (instead of a health examination following an interview, as in the present case). This study showed no differences in total serum cholesterol, HDL-cholesterol and systolic blood pressure between respondents and non-respondents, and only a slightly higher diastolic blood pressure $(0.7 \mathrm{mmHg})$ in non-respondents. ${ }^{33}$

Lastly, potential bias in relationships between some variables strongly related to non-participation was studied. In all cases, age- and gender-adjusted associations hardly changed when the HES participants alone were used in the analysis instead of all the HIS respondents. These findings are in agreement with previous studies which showed (with a single exception ${ }^{34}$ ) no significant bias in associations. ${ }^{6,10,19}$, $28,35,36,37$ and 38

Although these results are reassuring in that large biases could not be observed and the biases observed can be attributed to socio-economic differences (and thus, can be adjusted for), the possibility of selection dependent on non-observed factors still exists with the large non-participation rate of the HES. Also, this study only addressed the bias by non-participation among HIS respondents, who may already be a selective sample from the general population as the response rate of the HIS was only $56 \%$. Moreover, the sampling framework of the HIS excluded the institutional and homeless population, and those with difficulty speaking Dutch are also under-represented among HIS respondents. If those groups were included in the HIS and were invited to take part in the HES, their non- 
participation rates may further increase bias as these groups may have high nonresponse rates and poorer health.

A preceding HES in municipal health centres recruited participants directly from the general population and had a response rate of $45 \% .^{6}$ This is only slightly lower than the participation rate of $49 \%$ in the present HES, which was observed in subjects that had already participated in the HIS and had consented to being invited. This suggests that having a population of subjects willing to participate does not have a marked effect on participation rates. Together with the finding that factors influencing participation in the second stage of a survey seem to be similar to those influencing the first stage, this suggests that each time subjects are invited to take part in a study, they refuse with a certain probability. This probability depends on characteristics of the subject, e.g. socio-economic status, but also seems to be the result of a spur of the moment, random decision. This is reassuring in that it suggests that second-stage non-participation is partly a random process and that those participating are representative of those with similar characteristics who are not participating. It also implies that when high participation rates are required, multistage surveys are not the optimum method for data collection.

In conclusion, although the subjects in the HES sample are clearly different from the HIS population in terms of sociodemographic characteristics, socio-economic status, healthcare use and health status, no resulting bias could be demonstrated for measures of association. For absolute age-standardized outcome measures, some bias, mostly small, was seen for body height in men and for HDLcholesterol, fasting glucose and body weight in women. Therefore, caution is needed when using these outcome measures.

\section{References}

1 W.J.M.J. Appelboom, Non respons onderzoek gezondheidsenquete 1985, CBS, Voorburg (1984).

2 M. Van Baal, Respons analysis survey van POLS-een tussenrapportage, CBS, Heerlen (2000).

3 S. Te Riele, Vertekening door non-respons: hoe nauwkeurig zijn de uitkomsten van persoonsenquêtes?, CBS, Voorburg/Heerlen (2002).

4 B.F.M. Bakker and J. van Rooijen, One figure for the supply and demand of services, Netherlands official stat 15 (2000), pp. 40-46.

5 H.S.J. Picavet, National health surveys by mail or home interview: effects on response, J Epidemiol Community Health 55 (2001), pp. 408-413.

6 A.J. Van Loon, M. Tijhuis, H.S. Picavet, P.G. Surtees and J. Ormel, Survey non-response in the Netherlands. Effects on prevalence estimates and associations, Ann Epidemiol 13 (2003), pp. 105110.

7 G. Turrell, C. Patterson, B. Oldenburg, T. Gould and M.A. Roy, The socio-economic patterning of survey participation and non-response error in a multilevel study of food purchasing behaviour: areaand individual-level characteristics, Public Health Nutr 6 (2003), pp. 181-189.

8 K. Korkeila, S. Suominen, J. Ahvenainen, A. Ojanlatva, P. Rautava, H. Helenius and M. Koskenvuo, Non-response and related factors in a nation-wide health survey, Eur J Epidemiol 17 (2001), pp. 991999.

9 M. van den Akker, F. Buntinx, J.F. Metsemakers and J.A. Knottnerus, Morbidity in responders and non-responders in a register-based population survey, Fam Pract 15 (1998), pp. 261-263. 
$10 \mathrm{~S}$. Reijneveld and K. Stronks, The impact of response bias on estimates of health care utilization in a metropolitan area: the use of administrative data, Int J Epidemiol 28 (1999), pp. 1134-1140.

11 J.F. Etter and T.V. Perneger, Analysis of non-response bias in a mailed health survey, J Clin Epidemiol 50 (1997), pp. 1123-1128.

12 R.N. Forthofer, Investigation of nonresponse bias in NHANES II, Am J Epidemiol 117 (1983), pp. 507-515.

13 E. Pullen, D. Nutbeam and L. Moore, Demographic characteristics and health behaviours of consenters to medical examination. Results from the Welsh heart health survey, J Epidemiol Community Health 46 (1992), pp. 455-459.

14 J.W. Winkels and P.C.J. Everaers, Design of an integrated survey in the Netherlands. The case of POLS, Netherlands official stat 13 (1998), pp. 8-11.

$15 \mathrm{H}$. Smeets, Non-response van eerste generatie allochtonen in het POLS [Non-response of first generation immigrants in the periodical survey of conditions of living]. Heerlen/Voorburg, CBS, Bevolkings Trends (2004) 52(4): 92-97.

16 D.B. Rubin, Multiple imputation for nonresponse in surveys, Wiley, New York (1987).

17 Lazzeroni LG, Schenker N, Taylor JMG. Robustness of multiple imputation techniques to model misspecification. American Statistical Association's 1990 Proceedings of the Survey Research Methods Section 1990; 260-265

18 L.M. Lamers, Medical consumption of respondents and non-respondent to a mailed health survey, Eur J Public Health 7 (1997), pp. 267-271.

19 L.K. Heilbrun, A. Nomura and G.N. Stemmermann, The effects of non-response in a prospective study of cancer: 15-year follow-up, Int J Epidemiol 20 (1991), pp. 328-338. Abstract-EMBASE I Abstract-MEDLINE | Order Document | Abstract + References in Scopus | Cited By in Scopus

20 E. Ronmark, A. Lundqvist, B. Lundback and L. Nystrom, Non-responders to a postal questionnaire on respiratory symptoms and diseases, Eur J Epidemiol 15 (1999), pp. 293-299.

21 A.H. Mihelic and E.M. Crimmins, Loss to follow-up in a sample of Americans 70 years of age and older: the LSOA 1984-1990, J Gerontol B Psychol Sci Soc Sci 52 (1997), pp. S37-S48.

22 E. Shahar, A.R. Folsom and R. Jackson, The effect of nonresponse on prevalence estimates for a referent population: insights from a population-based cohort study. Atherosclerosis risk in communities (ARIC) study investigators, Ann Epidemiol 6 (1996), pp. 498-506.

23 R.C. Klesges, J.E. Williamson, G.W. Somes, G.W. Talcott, H.A. Lando and C.K. Haddock, A population comparison of participants and nonparticipants in a health survey, Am J Public Health 89 (1999), pp. 1228-1231.

24 A. Hill, J. Roberts, P. Ewings and D. Gunnell, Non-response bias in a lifestyle survey, J Public Health Med 19 (1997), pp. 203-207.

25 C.A. Macera, K.L. Jackson, D.R. Davis, J.J. Kronenfeld and S.N. Blair, Patterns of non-response to a mail survey, J Clin Epidemiol 43 (1990), pp. 1427-1430.

26 S. Eaker, R. Bergstrom, A. Bergstrom, H.O. Adami and O. Nyren, Response rate to mailed epidemiologic questionnaires: a population-based randomized trial of variations in design and mailing routines, Am J Epidemiol 147 (1998), pp. 74-82.

27 G.M. Jay, J. Liang, X. Liu and H. Sugisawa, Patterns of nonresponse in a national survey of elderly Japanese, J Gerontol 48 (1993), pp. S143-S152.

28 T.M. Eagan, G.E. Eide, A. Gulsvik and P.S. Bakke, Nonresponse in a community cohort study: predictors and consequences for exposure-disease associations, J Clin Epidemiol 55 (2002), pp. 775781. 
29 K. Kypri, S. Stephenson and J. Langley, Assessment of nonresponse bias in an internet survey of alcohol use, Alcohol clin Exp Res 28 (2004), pp. 630-634.

$30 \mathrm{~N}$. Bates and K. Creighton, The last five percent: what can we learn from difficult/late interviews?, Proceedings of the Annual Meetings of the American Statistical Association, US Census Bureau, Washington DC (2000).

31 J.R. Hochstim, A critical comparison of three strategies of collecting data from households, J Am Stat Assoc 62 (1967), pp. 976-989.

32 Fvd. Lucht and H.S.J. Picavet, Sociaal-economische verschillen in persoonskenmerken, [Socioeconomic differences in personal characterics], RIVM, Bilthoven (2003).

33 B.K. Jacobsen and D.S. Thelle, The Troms $\emptyset$ heart study: responders and non-responders to a health questionnaire, do they differ?, Scand J Soc Med 16 (1988), pp. 101-104.

34 L.J. Launer, A.W. Wind and D.J. Deeg, Nonresponse pattern and bias in a community-based crosssectional study of cognitive functioning among the elderly, Am J Epidemiol 139 (1994), pp. 803-812.

35 J. Brogger, P. Bakke, G.E. Eide and A. Gulsvik, Contribution of follow-up of nonresponders to prevalence and risk estimates: a Norwegian respiratory health survey, Am J Epidemiol 157 (2003), pp. 558-566.

36 J. Siemiatycki and S. Campbell, Nonresponse bias and early versus all responders in mail and telephone surveys, Am J Epidemiol 120 (1984), pp. 291-301.

37 P. Bakke, A. Gulsvik, P. Lilleng, O. Overa, R. Hanoa and G.E. Eide, Postal survey on airborne occupational exposure and respiratory disorders in Norway: causes and consequences of nonresponse, J Epidemiol Community Health 44 (1990), pp. 316-320.

38 M.A. Austin, M.H. Criqui, E. Barrett-Connor and M.J. Holdbrook, The effect of response bias on the odds ratio, Am J Epidemiol 114 (1981), pp. 137-143. 